\title{
Socio-demographic Characteristics and Psychosocial Stressors in the Children and Adolescents with Somatoform Disorders
}

\author{
Jalan $\mathrm{RK}^{1}$, Adhikari J², Belbase $\mathrm{M}^{3}$
}

\begin{abstract}
Introduction: Somatoform disorders are characterized by physical symptoms that suggest a medical condition, and which are not fully explainable by general medical condition, or by the direct effects of a substance, or by another mental disorder. Objectives: to study the socio-demographic characteristics and psychosocial stressors in children and adolescents with somatoform disorders. Methods: From $1^{\text {st }}$ January, 2018 to $30^{\text {th }}$ June 2018, Children and adolescents from 3 to 18 years of age with unexplained physical symptoms were evaluated using DSM - IV criteria. Detailed evaluation followed for those meeting inclusion criteria. Results: Among 65 patients $(18,27.69 \%$ boys and $47,72.31 \%$ girls) meeting inclusion criteria, conversion disorder was the most common (37, $56.92 \%)$, followed by undifferentiated somatoform disorder $(15,23.08 \%)$. Girls were significantly more represented among conversion disorder patients compared to other groups of somatoform disorders $\left(68.08 \%\right.$ vs. $\left.27.78 \%, X^{2}=8.63, p<0.01\right)$ Stressors were identified in $95 \%$ and acute precipitating stressors were present in $75 \%$ patients. Both the boys and girls had significantly higher rates of academic problems. Boys found to have social and environmental problems while girls had problems in primary support group. Conclusion: Somatoform disorder, particularly conversion disorder is more common and it is found more in girls. Academic problems, poor interpersonal relations and conflict in the family are the important psychosocial stressors.
\end{abstract}

Key words: Conversion Disorder, Psychosocial Stressors, Socio-demographic characteristics, Somatoform disorder.

\section{INTRODUCTION}

Somatoform disorders are characterized by physical symptoms that suggest a medical condition and which are not fully explainable by a general medical condition, by the direct effects of a substance, or by another psychiatric condition. In contrast to factitious disorders and malingering, the physical symptoms are not intentional ${ }^{1}$. Medically unexplained somatic symptoms are a common problem in adults and these physical symptoms begin during childhood and adolescence. Excessive somatic complaints and associated illness behavior can lead to serious developmental problems when accompanied by school absences, academic failure, and withdrawal from normal social activities. Moreover, the search for diagnoses and cures of these persistent physical complaints can place children at risk

1. Dr. Rekha K. Jalan

2. Dr. Jyoti Adhikari

3. Dr. Mohan Belbase

Address for correspondance:

Dr. Rekha K. Jalan

Assistant Professor of Clinical Psychology

Department of Psychiatry

Nepalgunj Medical College \& Teaching Hospital

Kohalpur, Banke, Nepal

Email:jalanrekha@hotmail.com of unnecessary medical tests and treatments, which can be very expensive for the family, medical profession and society. The direct and indirect resource consumption by these patients can be enormous ${ }^{2}$. During this time of increasing attention to the cost of health care, there is a growing concern about the expenditure of both human and economic resources to deal with pediatric somatization.

More than one third of patients in outpatient pediatric care report medically unexplained physical symptoms associated with functional and emotional impairments ${ }^{3}$. In a recent prospective study, ${ }^{4} 52 \%$ of patients had conversion disorder, $13.3 \%$ had undifferentiated somatoform disorder, $4 \%$ had somatoform disorder not otherwise specified, $2 \%$ somatization disorder, $8.6 \%$ pain disorder and the rest had other psychiatric disorders ${ }^{5}$. Diagnostic criteria of these disorders are typically met before 25 years of age, but initial symptoms are often present by adolescence. The developmental differences between adults and children lead to different presentations. Studies in children are sparse and those evaluating somatoform disorders are even lesser. Understanding of the psychological etiology of somatoform disorders highlight the patients' tendency to express emotional distress through physical symptoms. This study was done with the aim of determining socio-demographic profile and psychosocial stressors in somatoform disorders among children and adolescents. 


\section{MATERIAL AND METHODS}

A descriptive cross-sectional study was carried out with 65 children and adolescents having somatoform disorder from 3 to 18 years of age diagnosed as per the DSM-IV criteria, ${ }^{1}$ attending to the outpatient Department of Psychiatry and referred to the Clinical Psychology unit for Psychological Intervention from $1^{\text {st }}$ January, 2018 to $30^{\text {th }}$ June, 2018, Nepalgunj Medical College (NGMC), Kohalpur. Out of 65 patients 38 cases were referred from the Department of Pediatric. Ethical consideration was given due importance. Consent from the parents was taken to participate in the study and the information obtained was kept confidential. This study was started after approval of Institutional Review Committee (IRC) of Nepalgunj Medical College, Teaching Hospital, Kohalpur. The patients suffering from physical illnesses, organic brain disease, psychiatric co-morbidity such as depression and anxiety, substance abuse, learning disability, and those having language barrier were excluded from the study. The participating patients were examined by the psychiatrists and diagnosed as somatoform disorder. The patients were assessed for socio-demographic profile and psychosocial stressors (present in school or family and in social environment in the past 3 months of onset of illness) by the clinical psychologist. The revised socio-economic status (SES) scale of $B$. Kuppuswamy- revised for 2015 was used for the assessment of $\mathrm{SES}^{6}$. Data were analyzed using Statistical Packages in Social Sciences (SPSS) software.

\section{RESULTS}

Table I provides socio-demographic characteristics of the sample. Total 65 patients with the diagnosis of somatoform disorder were referred to the Clinical Psychology Unit for psychological intervention (assessment and counseling/psychotherapy). 38 (58.46\%) clients out of 65 were referred from the department of pediatric. Majority of the subjects were female (72.31\%), students $(93.85 \%)$, and unmarried (89.23\%). Majority of the subjects were in the age group of $7-12$ years (52.31\%) and second majority was from the age group $13-18$ years (44.62\%). Most of the study subjects were students (93.85\%) and rest of them were housewives (6.15\%). Most of the subjects (84.62\%) belonged to the nuclear family. Majority of them had a rural background (66.15\%).

Table II illustrates the diagnostic characteristics of the patients. Majority $(37,56.92 \%)$ of the patients were diagnosed as conversion disorder. Patients with other group of somatoform disorders were 28 (43.08\%). Girls in comparison to boys were significantly more represented among conversion disorder patients compared to other groups of somatoform disorders (68.08\% vs. $\left.27.78 \%, \mathrm{X}^{2}=8.63, \mathrm{p}<0.01\right)$.

Table III reveals psychosocial stressors in the subjects. Majority $(80.00 \%)$ of the patients having problems associated with education and literacy and second majority (26.15\%) facing difficulties associated with primary support group including family circumstances/conflicts followed by social and environmental problems (20.00\%). Other stressors present are family history of morbidity and disability (10.77\%), housing and economic hardships (9.23\%) and other psychosocial circumstances (6.15\%).

Conversion disorder (56.92\%) was the most common diagnosis followed by undifferentiated somatoform disorder (23.08\%). Pseudo seizure (89.19\%) was the most common type of clinical presentation in conversion disorder. No subjects presented with isolated sensory symptoms.

\begin{tabular}{|c|c|c|c|}
\hline Variable & Male & Female & $\begin{array}{l}\text { Total } \\
\text { N (\%) }\end{array}$ \\
\hline \multicolumn{4}{|l|}{ Age Range } \\
\hline $0-6$ & $2(3.08 \%)$ & $0(0.00 \%)$ & $2(3.08 \%)$ \\
\hline $7-12$ & $13(20.00 \%)$ & $21(32.31 \%)$ & $34(52.31 \%)$ \\
\hline $13-18$ & $3(4.62 \%)$ & $26(40.00 \%)$ & $29(44.62 \%)$ \\
\hline Total & $18(27.69 \%)$ & 47 (72.31\%) & $65(100.00 \%)$ \\
\hline \multicolumn{4}{|l|}{ Education } \\
\hline Primary & $8(12.31 \%)$ & $8(12.31 \%)$ & $16(24.62 \%)$ \\
\hline Secondary & $6(9.23 \%)$ & $20(30.77 \%)$ & $26(40.00 \%)$ \\
\hline Higher-secondary & $4(6.15 \%)$ & $17(26.15 \%)$ & 21 (32.31\%) \\
\hline Intermediate & $0(0.00 \%)$ & $2(3.08 \%)$ & $2(3.08 \%)$ \\
\hline Total & $18(27.69 \%)$ & 47 (72.31\%) & $65(100.00 \%)$ \\
\hline \multicolumn{4}{|l|}{ Occupation } \\
\hline Student & $18(27.69 \%)$ & $43(66.16 \%)$ & $61(93.85 \%)$ \\
\hline Housewife & $0(0.00 \%)$ & $4(6.15 \%)$ & $4(6.15 \%)$ \\
\hline Business & $0(0.00 \%)$ & $0(0.00 \%)$ & $0(0.00 \%)$ \\
\hline Service & $0(0.00 \%)$ & $0(0.00 \%)$ & $0(0.00 \%)$ \\
\hline Total & $18(27.69 \%)$ & $47(72.31 \%)$ & $65(100.00 \%)$ \\
\hline \multicolumn{4}{|c|}{ Socio-economic status } \\
\hline Lower & $0(0.00 \%)$ & $0(0.00 \%)$ & $0(0.00 \%)$ \\
\hline Upper Lower & $5(7.69 \%)$ & $6(9.23 \%)$ & $11(16.92)$ \\
\hline Lower Middle & $4(6.15 \%)$ & $14(21.54 \%)$ & $18(27.69 \%)$ \\
\hline Upper Middle & $7(10.77 \%)$ & $25(38.46 \%)$ & $32(49.23 \%)$ \\
\hline Upper & $2(3.08 \%)$ & $2(3.08 \%)$ & $4(6.15 \%)$ \\
\hline Total & $18(27.69 \%)$ & $47(72.31 \%)$ & $65(100.00 \%)$ \\
\hline \multicolumn{4}{|l|}{ Marital status } \\
\hline Married & $0(0.00 \%)$ & $7(10.77 \%)$ & $7(10.77 \%)$ \\
\hline Unmarried & $18(27.69 \%)$ & $40(61.53 \%)$ & $58(89.23 \%)$ \\
\hline Total & $18(27.69 \%)$ & $47(72.31 \%)$ & $65(100.00 \%)$ \\
\hline \multicolumn{4}{|l|}{ Family Type } \\
\hline Nuclear & $15(23.08 \%)$ & $40(61.54 \%)$ & $55(84.62 \%)$ \\
\hline Joint & $3(4.62 \%)$ & $7(10.77 \%)$ & $10(15.38 \%)$ \\
\hline Total & $18(27.69 \%)$ & $47(72.31 \%)$ & $65(100.00 \%)$ \\
\hline \multicolumn{4}{|l|}{ Area of residence } \\
\hline Rural & $11(16.92 \%)$ & $32(49.23 \%)$ & $43(66.15 \%)$ \\
\hline Urban & $7(10.77 \%)$ & $15(23.08 \%)$ & $22(33.85 \%$ \\
\hline Total & $18(27.69 \%)$ & $47(72.31 \%)$ & $65(100.00 \%)$ \\
\hline
\end{tabular}

Table I: Socio-demographic Characteristics 


\begin{tabular}{|l|l|l|l|l|}
\hline $\begin{array}{l}\text { Somatoform } \\
\text { Disorders (SDs) }\end{array}$ & $\begin{array}{l}\text { Male } \\
(\mathbf{N = 1 8 )}\end{array}$ & $\begin{array}{l}\text { Female } \\
(\mathbf{N}=47)\end{array}$ & $\begin{array}{l}\text { Total } \\
(\mathbf{N}=65)\end{array}$ & $\begin{array}{l}\mathbf{X}^{2} \\
\text { Value }\end{array}$ \\
\hline $\begin{array}{l}\text { Conversion } \\
\text { disorder }\end{array}$ & $\begin{array}{l}5 \\
(27.78 \%)\end{array}$ & $\begin{array}{l}32 \\
(68.08 \%)\end{array}$ & $\begin{array}{l}37 \\
(56.92 \%)\end{array}$ & \multirow{2}{*}{$8.63^{*}$} \\
\cline { 1 - 4 } $\begin{array}{l}\text { Other group of } \\
\text { somatoform } \\
\text { disorders }\end{array}$ & $\begin{array}{l}13 \\
(72.22 \%)\end{array}$ & $\begin{array}{l}15 \\
(31.92 \%)\end{array}$ & $\begin{array}{l}28 \\
(43.08 \%)\end{array}$ & \\
\hline
\end{tabular}

Table II: Diagnostic characteristics (*significant at $P<0.01$ )

\begin{tabular}{|l|l|l|l|}
\hline Psychosocial Stressors & $\begin{array}{l}\text { Male } \\
(\mathbf{N}=\mathbf{1 8})\end{array}$ & $\begin{array}{l}\text { Female } \\
(\mathbf{N}=\mathbf{4 7})\end{array}$ & $\begin{array}{l}\text { Total } \\
\mathbf{( N = 6 5 )}\end{array}$ \\
\hline No stress & $0(0.00 \%)$ & $0(0.00 \%)$ & $0(0.00 \%)$ \\
\hline Negative childhood events & $0(0.00 \%)$ & $0(0.00 \%)$ & $0(0.00 \%)$ \\
\hline $\begin{array}{l}\text { Family history of morbidity } \\
\text { and disability }\end{array}$ & $2(11.11 \%)$ & $5(10.64 \%)$ & $7(10.77 \%)$ \\
\hline $\begin{array}{l}\text { Lifestyle and life } \\
\text { management difficulties }\end{array}$ & $0(0.00 \%)$ & $0(0.00 \%)$ & $0(0.00 \%)$ \\
\hline $\begin{array}{l}\text { Education and literacy } \\
\text { related problems }\end{array}$ & $14(77.78 \%)$ & $38(80.85 \%)$ & $52(80.00 \%)$ \\
\hline $\begin{array}{l}\text { Primary support group } \\
\text { including family } \\
\text { circumstances and conflict }\end{array}$ & $3(16.67 \%)$ & $14(29.78 \%)$ & $17(26.15 \%)$ \\
\hline $\begin{array}{l}\text { Social and environmental } \\
\text { problems }\end{array}$ & $8(44.44 \%)$ & $5(10.64 \%)$ & $13(20.00 \%)$ \\
\hline $\begin{array}{l}\text { Housing or economic } \\
\text { hardships }\end{array}$ & $2(11.11 \%)$ & $4(8.51 \%)$ & $6(9.23 \%)$ \\
\hline Physical environment & $0(0.00 \%)$ & $0(0.00 \%)$ & $0(0.00 \%)$ \\
\hline $\begin{array}{l}\text { Other psychosocial } \\
\text { circumstances }\end{array}$ & $1(5.56 \%)$ & $3(6.38 \%)$ & $4(6.15 \%)$ \\
\hline Legal & $0(0.00 \%)$ & $0(0.00 \%)$ & $0(0.00 \%)$ \\
\hline
\end{tabular}

Table III: Types of Psychosocial Stressors

\section{DISCUSSION}

In the present study, somatoform disorders were found to be higher in female $(72.31 \%)$ than in males $(27.69 \%)$. Majority (52.31\%) of patients were from the age group of 7-12 years followed by those (44.62\%) in 13-18 years of age group. Excess of female patients compared to males in conversion disorder is a feature of adult patients, but it has been also seen in another pediatric study. ${ }^{5}$ In the present study, girls were more likely to present with a somatoform disorder as compare to boys. This difference of sex representation is more apparent among conversion disorders. The girl child grows in an atmosphere of inhibited emotional ventilation. This is coupled with the pressure of puberty possibly account for the higher occurrence of conversion disorders among girls ${ }^{7}$.

Occupation pattern revealed that students and house wives found to be more at risk as the sample comprised of these two occupational groups ( Students $=93.85 \%$ and House wife $=6.15 \%$ ). While analyzing the nature of stress, students were found to be more demanded academically. Whereas social demands upon married girls imposed stressors. Marriage itself is a major life event where a girl has to prepare herself psychologically to deal with lots of familial and social difficulties. Furthermore, the caring and raring responsibilities and their own security in family directly contributed in increased emotional conflict.

More than half of the patients belonged to the middle socioeconomic status and nuclear type of family (84.62\%). Majority $(66.15 \%)$ of the patients belonged to rural background which is consistent with another study ${ }^{8}$. "It may be hypothesized that there is more pressure on children from nuclear families as the social and emotional support provided by the presence of grand parents, uncle and aunt will be missing.The condition was also more common in middle socio-economic status families, which again suggests the changing social pattern where middle class is striving hard to achieve higher social and financial status. In this situation, the child may be coaxed or pressurized into performance which is beyond his/her abilities. An acute stress against this backdrop may manifest as somatic symptom in the child.

Psychosocial stressors have been implicated in the etiology of somatoform disorders. Acute stressors related to education and literacy (80.00\%) like academic problems and school examination. The reason behind which is poor quality of teaching in schools, poor monitoring of studies at home by the parents and unrealistic expectation from the child by parents. Problem in primary support group (26.15\%) like family conflict, and social and environmental problems (20.00\%) like change of school, joining hostel, poor interpersonal relations etc. were identified in a large number of cases. Symptoms started shortly after the stressful event. Other study also supported the similar findings in other studies where stress relating to "studies" was the most common precipitating factor ${ }^{9}$. Poor quality of teaching in school, poor monitoring of studies at home by the parents and unrealistic expectations from the child by the parents were found to be problem areas.

Other stress factors were family conflict, over-protective parents, and peer problems. Problem in primary support group (26.15\%) like family conflict, communication problem in family was found as stress factors in the present study that is consistent with the findings in other studies done in this area ${ }^{10,11}$. Girl child was at a disadvantage as she was more 
involved with house hold chores.

The symptomatic presentation of pseudoseizures and loss of ability to move selected body part such as loss of voice, inability to move hand or legs in conversion disorder and abdominal pain, headache, chest pain in other somatoform disorders were common complaints. The cultural and social acceptance of physical symptoms as a mean of getting attention from significant others and relief from core conflictual issue can be considered as a major choice for these symptoms.

\section{CONCLUSION}

The present study described the characteristics of children and adolescent patients with somatoform disorders from a mental health perspective. Increased awareness among pediatric treatment providers of both medical and psychosocial characteristics of children and adolescents with somatic presentation may help in early detection of somatoform disorders; reduce the risk of excessive medical intervention. Emotional factors and advantages of playing the "sick role" play a part in continuation of symptoms. The identification of stressors helps in formulating appropriate psycho-education to the family and psychosocial management of the patient.

Future studies on the development of standardized approaches for the assessment and management of hospitalized pediatric patients with psychosomatic presentation will improve clinical practice and patients' outcome.

\section{REFRENCES}

1. American Psychiatric Association. Diagnostic and Statistical Manual of Mental Disorders, $4^{\text {th }}$ ed, Washington DC: APA, 1994.

2. Labott SM, Preisman RC, Popovich J, lannuzzi MC Health care utilization of the somatizing patients in a pulmonary subspecialty clinic. Psychosomatics Res., 1995; 36: 122128.

3. Andersen JM, Woolfolk RL, Allen LA, et al. Physical symptoms and psychosocial correlates of somatization in pediatric primary care. Clin Pediatr (Phila), 2011; 50(10): 904-909.

4. Pehlivanturk B, Unal F. Conversion disorder in children and adolescents; a 4-year follow up study. Journal of Psychosomatics, 2002; 52: 187-191.

5. Trivedi JK, Singh H, Sinha PK. A clinical study of hysteria in children and adolescents. Indian Journal of Psychiatry, 1982; $24: 70-74$.
6. Guru Raj MS, Silpa S, Maheswaran R. Revised Socio Economic Status Scale for Urban and Rural India - Revised for 2015. The Scientific Journal for Theory and Practice of Socio-economic Development, 2015; 4(7): 167-174.

7. De Sousa A, De Sousa DA. Child Psychiatry. $1^{\text {st }}$ ed. Bombay: Bhalani Book Depot; 1987.

8. Gupta V, Singh A, Upadhyay SK, Bhatia BD . Clinical and Socio-demographic profile of conversion disorder in children. Indian Journal of Pediatrics, 2011; 78: 283-28.

9. Deka K, Chaudhary PK, Bora K, Kalita P. A study of clinical correlates and socio-demographic profile in conversion disorder. Indian Journal of Psychiatry, 2007; 49: 205-207.

10. Maloney M. Diagnosing hysterical conversion reaction in childhood. Journal of Pediatrics, 1980; 97: 1016-1020.

11. Murase S, Sugiyama T, Ishii T, Wakako R, Ohta T. Polysymptomatic conversion disorder in childhood and adolescence in Japan. Psychotherapy Psychosomatics; 2000; 69: 132-135. 